\section{Letter to the Editor}

Transfusion Medicine

Ann Lab Med 2020;40:493-499

https://doi.org/10.3343/alm.2020.40.6.493

ISSN 2234-3806 elSSN 2234-3814
ANNALS OF

LABORATORY

MEDICINE

\title{
Human Platelet Antigen Datasets for Malays, Chinese, and Indians in Peninsular Malaysia
}

\begin{abstract}
Che Ghazali Norul Hajar (), M.DSc. ${ }^{1}$, Zulkifli Zefarina (), M.D., M.Path. ${ }^{2}$, Nor Suhaila Md. Riffin (i), M.D., M.Path. ${ }^{3}$,

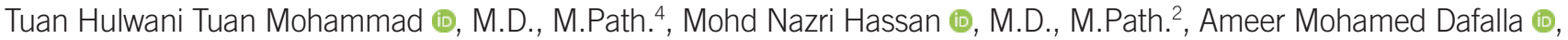
Ph.D. ${ }^{5}$, Gehad ElGhazali $\mathbb{1}$, M.D., M.Path. ${ }^{6}$, Geoffrey Keith Chambers $\mathbb{C}^{\circ}$, Ph.D. ${ }^{7}$, and Hisham Atan Edinur $\mathbb{0}$, Ph.D. ${ }^{1}$

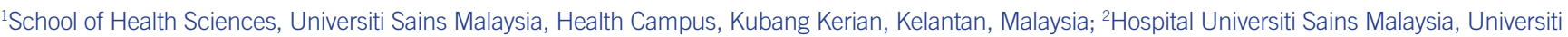
Sains Malaysia, Kubang Kerian, Kelantan, Malaysia; ${ }^{3}$ Hospital Sultan Haji Ahmad Shah, Temerloh, Pahang, Malaysia; ${ }^{4}$ Hospital Seberang Jaya, Perai, Pulau Pinang, Malaysia; ${ }^{5} \mathrm{HLA}$ Laboratory, National Cancer Institute, University of Gezira, Wad Medani, Sudan; ' ${ }^{6}$ epartment of Immunology, Pathology and Laboratory Medicine Services, Sheikh Khalifa Medical City, Abu Dhabi, United Arab Emirates; ${ }^{7}$ School of Biological Sciences, Victoria University of Wellington, Wellington, New Zealand
\end{abstract}

\section{Dear Editor,}

Human platelet antigens (HPAs) are genetically inherited polymorphic glycoproteins expressed on the platelet membrane [1]. HPAs are transfusion and gestation compatibility determinants, and HPA alloantibodies have been reported in post-transfusion purpura, platelet transfusion refractoriness, and neonatal alloimmune thrombocytopenia (NAIT) cases [2].

Previously, we reported HPA allele frequency data for Malay subethnic groups [3] and Orang Asli [4] in Peninsular Malaysia. These earlier studies have provided a valuable preliminary source of genetic information for health assessments and population genetics. However, a complete picture of the genetic structure in Peninsular Malaysia should also include data from Malays (i.e., Deutero-Malays), Chinese, and Indians, as they represent $>75 \%$ of the total population [5]. There are some HPA data for Malays, Chinese, and Indians reported by Tan, et al. [6]; the present HPA data can be compared with those data.

We typed HPA- 1 to -6 and HPA-15 loci in blood samples obtained with informed consent from a total of 222 individuals registered as voluntary, non-remunerated blood donors at the Hospital Universiti Sains Malaysia (Kelantan), Hospital Seberang
Jaya (Pulau Pinang), and Temerloh Hospital (Pahang) in Malaysia. The individuals were un-admixed with no history of intermarriage with other ethnic groups for three generations. The ethnicity classes of these samples were assigned as Malay $(\mathrm{N}=97)$, Chinese ( $N=77)$, and Indian ( $N=48)$ based on individual pedigree information. Our proposed study was reviewed and approved by the Human Ethical Committee, Universiti Sains Malaysia, Malaysia, and the Medical Research and Ethics Committee, Ministry of Health, Malaysia. The HPA typing and data analysis were performed as previously described by Wan Syafawati, et al. [3] and Syafawati et al. [4]. Briefly, isolated genomic DNA was amplified using polymerase chain reaction and sequence-specific primers (PCR-SSP) for HPA-1 to -6 and -15 . Amplified products were then separated using agarose gel electrophoresis ( $2 \%$ agarose gels stained with ethidium bromide) and visualised using a UV photometer (Quantum ST4-1000/20M, VilberLourmat, Deutschland GmbH, Eberhardzell, Germany). The separated band patterns (amplified allele-specific HPA products and human growth hormone) were then compared with a 100 base pair DNA size standard (Bioline, London, UK). HPA allele frequencies were determined by dividing the allele count numbers
Received: January 31, 2020

Revision received: March 7, 2020

Accepted: May 21, 2020

Corresponding author: Hisham Atan Edinur, Ph.D.

School of Health Sciences Health Campus, Universiti Sains Malaysia, 16150 Kubang Kerian, Kelantan, Malaysia

Tel: +60 9-7677641, Fax: +60 9-7677515, E-mail: edinur@usm.my

\section{(c) (1) $(9$}

\section{(C) Korean Society for Laboratory Medicine}

This is an Open Access article distributed under the terms of the Creative Commons Attribution Non-Commercial License (https://creativecommons.org/licenses/by-nc/4.0) which permits unrestricted non-commercial use, distribution, and reproduction in any medium, provided the original work is properly cited. 
Table 1. HPA allele frequency distribution in the present and previous studies

\begin{tabular}{|c|c|c|c|c|c|c|c|c|c|c|c|c|c|c|c|}
\hline Population & (N) & 1a & $1 \mathrm{~b}$ & $2 a$ & $2 b$ & $3 a$ & $3 b$ & $4 a$ & $4 \mathrm{~b}$ & $5 a$ & $5 b$ & $6 a$ & $6 b$ & $15 a$ & $15 b$ \\
\hline Malays (present study) & 97 & 0.985 & 0.015 & 0.969 & 0.031 & 0.510 & 0.490 & 1.000 & 0.000 & 0.990 & 0.010 & 0.990 & 0.010 & 0.479 & 0.521 \\
\hline Chinese (present study) & 77 & 1.000 & 0.000 & 0.980 & 0.020 & 0.591 & 0.410 & 1.000 & 0.000 & 0.987 & 0.013 & 0.994 & 0.006 & 0.526 & 0.474 \\
\hline Indians (present study) & 47 & 0.979 & 0.021 & 0.969 & 0.031 & 0.521 & 0.479 & 1.000 & 0.000 & 0.959 & 0.041 & 0.990 & 0.010 & 0.375 & 0.625 \\
\hline Banjar [3] & 30 & 1.000 & 0.000 & 0.950 & 0.050 & 0.616 & 0.384 & 0.950 & 0.050 & 0.950 & 0.050 & 0.980 & 0.020 & 0.480 & 0.520 \\
\hline Bugis [3] & 37 & 1.000 & 0.000 & 1.000 & 0.000 & 0.554 & 0.446 & 1.000 & 0.000 & 0.950 & 0.050 & 0.910 & 0.090 & 0.620 & 0.380 \\
\hline Champa [3] & 51 & 0.980 & 0.020 & 0.970 & 0.030 & 0.677 & 0.323 & 1.000 & 0.000 & 0.990 & 0.010 & 0.980 & 0.090 & 0.480 & 0.520 \\
\hline Jawa [3] & 39 & 1.000 & 0.000 & 1.000 & 0.000 & 0.628 & 0.372 & 1.000 & 0.000 & 0.960 & 0.040 & 1.000 & 0.000 & 0.450 & 0.550 \\
\hline Kelantan [3] & 35 & 1.000 & 0.000 & 0.940 & 0.060 & 0.571 & 0.429 & 1.000 & 0.000 & 1.000 & 0.000 & 0.990 & 0.010 & 0.490 & 0.510 \\
\hline Orang Kanaq [4] & 11 & 1.000 & 0.000 & 1.000 & 0.000 & 0.818 & 0.182 & 1.000 & 0.000 & 1.000 & 0.000 & 1.000 & 0.000 & 0.909 & 0.091 \\
\hline Batek [4] & 27 & 1.000 & 0.000 & 1.000 & 0.000 & 0.500 & 0.500 & 1.000 & 0.000 & 0.852 & 0.148 & 1.000 & 0.000 & 0.000 & 1.000 \\
\hline Lanoh [4] & 25 & 1.000 & 0.000 & 1.000 & 0.000 & 0.640 & 0.360 & 1.000 & 0.000 & 1.000 & 0.000 & 1.000 & 0.000 & 0.260 & 0.740 \\
\hline Kensiu [4] & 36 & 0.958 & 0.042 & 1.000 & 0.000 & 0.875 & 0.125 & 1.000 & 0.000 & 0.847 & 0.153 & 1.000 & 0.000 & 0.361 & 0.639 \\
\hline Che Wong [4] & 26 & 1.000 & 0.000 & 1.000 & 0.000 & 0.423 & 0.577 & 1.000 & 0.000 & 0.788 & 0.212 & 1.000 & 0.000 & 0.500 & 0.500 \\
\hline Semai [4] & 40 & 0.988 & 0.012 & 1.000 & 0.000 & 0.671 & 0.329 & 1.000 & 0.000 & 0.890 & 0.110 & 1.000 & 0.000 & 0.524 & 0.476 \\
\hline Malays [6] & 200 & 0.975 & 0.025 & 0.963 & 0.037 & 0.503 & 0.497 & 0.995 & 0.005 & 0.950 & 0.050 & 0.993 & 0.007 & 0.515 & 0.485 \\
\hline Chinese [6] & 200 & 1.000 & 0.000 & 0.967 & 0.033 & 0.573 & 0.427 & 0.998 & 0.002 & 0.983 & 0.017 & 0.983 & 0.017 & 0.498 & 0.502 \\
\hline Indians [6] & 200 & 0.885 & 0.115 & 0.960 & 0.040 & 0.620 & 0.380 & 0.995 & 0.005 & 0.940 & 0.060 & 0.995 & 0.005 & 0.408 & 0.592 \\
\hline
\end{tabular}

by the total numbers of chromosomes ( $2 n)$ tested. Genetic differentiations between pairs of HPA population datasets were evaluated using Arlequin version 3.0 software [7] and were considered statistically significant at $P<0.05$.

The present and previously reported HPA datasets of various population groups in Peninsular Malaysia are shown in Table 1 $[3,4,6]$. These HPA datasets reveal that Malays and Chinese differ significantly $(P<0.05)$ from Indians (Table 2$)$. However, no significant differences were observed between the HPA datasets of Malays and Chinese. Importantly, Malays, Chinese, and Indians are the modern-day descendants of ancestrally unrelated ethnic groups in Peninsular Malaysia; the inability of the HPA datasets to differentiate between Malays and Chinese needs to be resolved using more informative genetic markers, including genome-wide single nucleotide polymorphisms and whole genome sequencing data [8]. In addition, some of the ancestral relationships might also be obscured by demographic processes such as natural selection and founder effects. Of these forces, natural selection is expected to have a greater effect on genes that are important in the medical field such as HPA, compared with other regions in the human genome [1]. For example, some differences observed between ancestrally related Proto-Malays (Orang Kanaq), Malay subethnic groups, and Malays could possibly be attributed to gene flow via admixture and historical events at the population level (as mentioned earlier), rather than different origins (Table 2) [8].

In our view, HPA datasets for various population groups in Peninsular Malaysia (Tables 1 and 2) also have significant value for health and have been identified as genetic risk factors for many diseases [9]. The risk of HPA alloimmunization in Peninsular Malaysia might be expected to be most frequently associated with alloantibodies against HPA-3 and HPA-15 products, as these are the most polymorphic loci observed within and between population groups in Peninsular Malaysia (Tables 1 and 2). Our hypothesis regarding HPA alloimmunization risk is supported by the presence of HPA-1a, -3a, -5a, and -15b alloantibodies in most of the NAIT cases and multi-transfused thrombocytopenia patients in Malaysia [10]. Therefore, implementation of HPA typing could reduce the incidence of HPA alloimmunization cases in Malaysia.

In conclusion, to the best of our knowledge, our study is the first complete representative collection of HPA datasets for all population groups in Peninsular Malaysia. These datasets can be used for developing better healthcare services and as a reference standard for identifying genetic risk factors for many diseases associated with HPAs. 


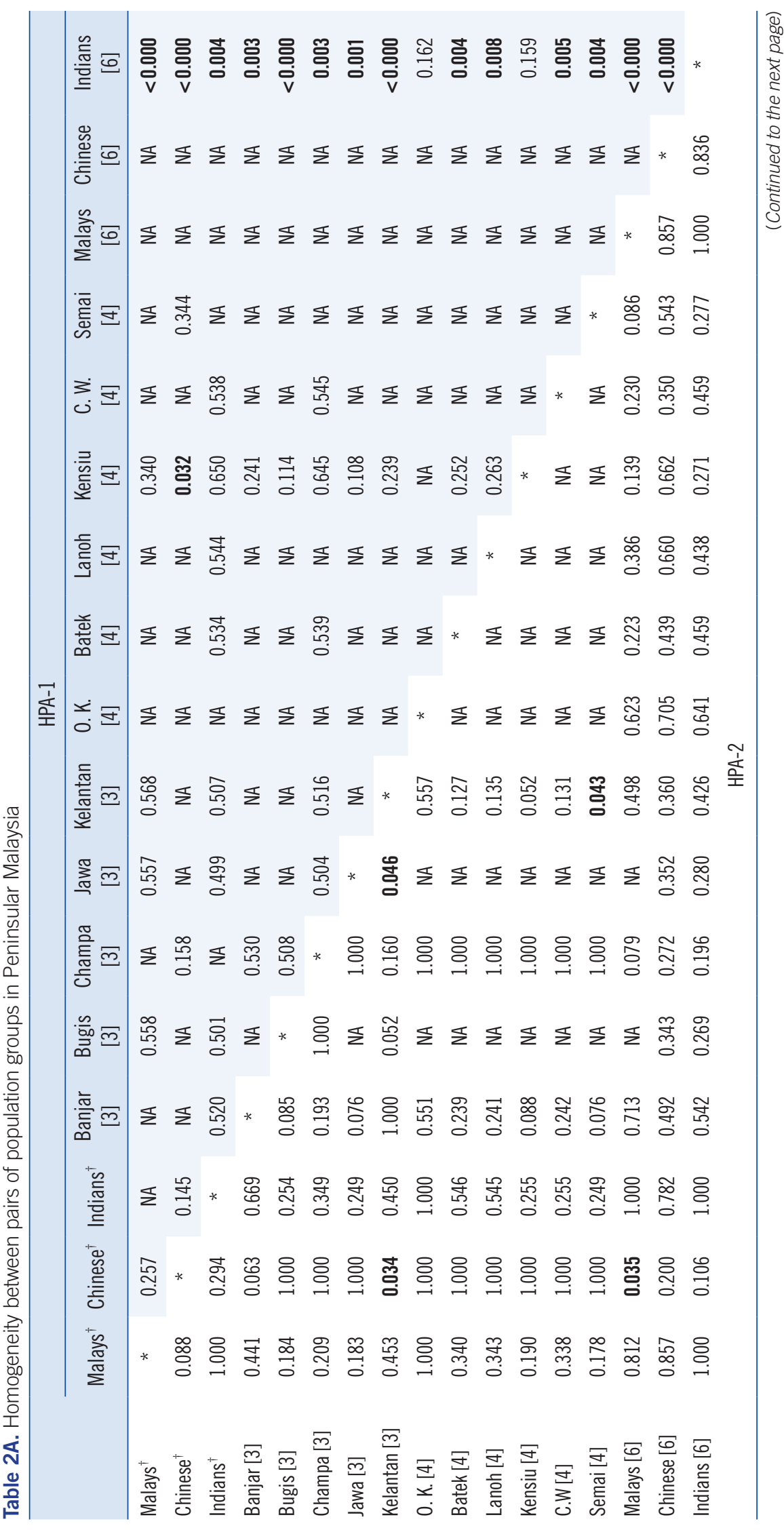




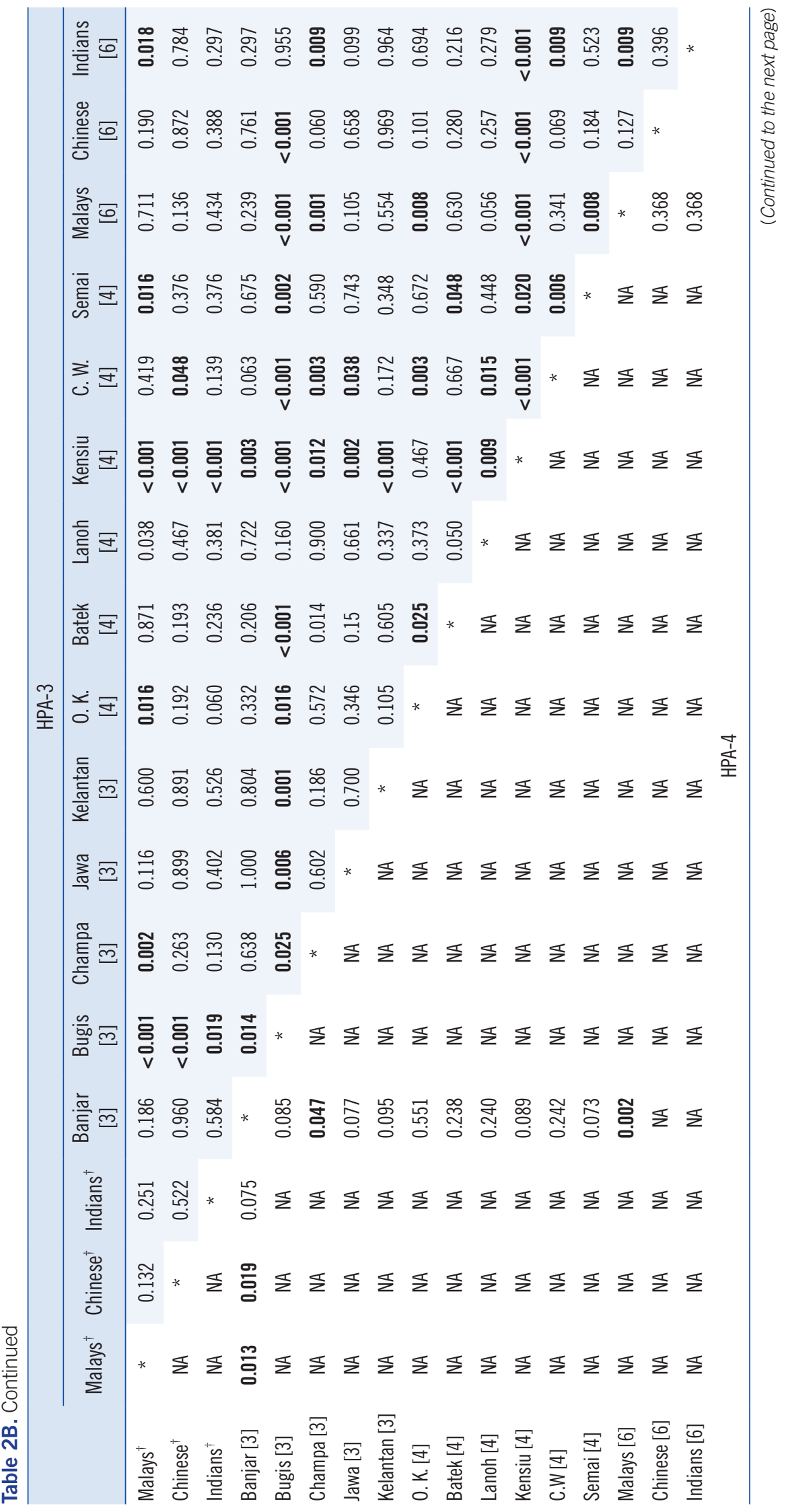




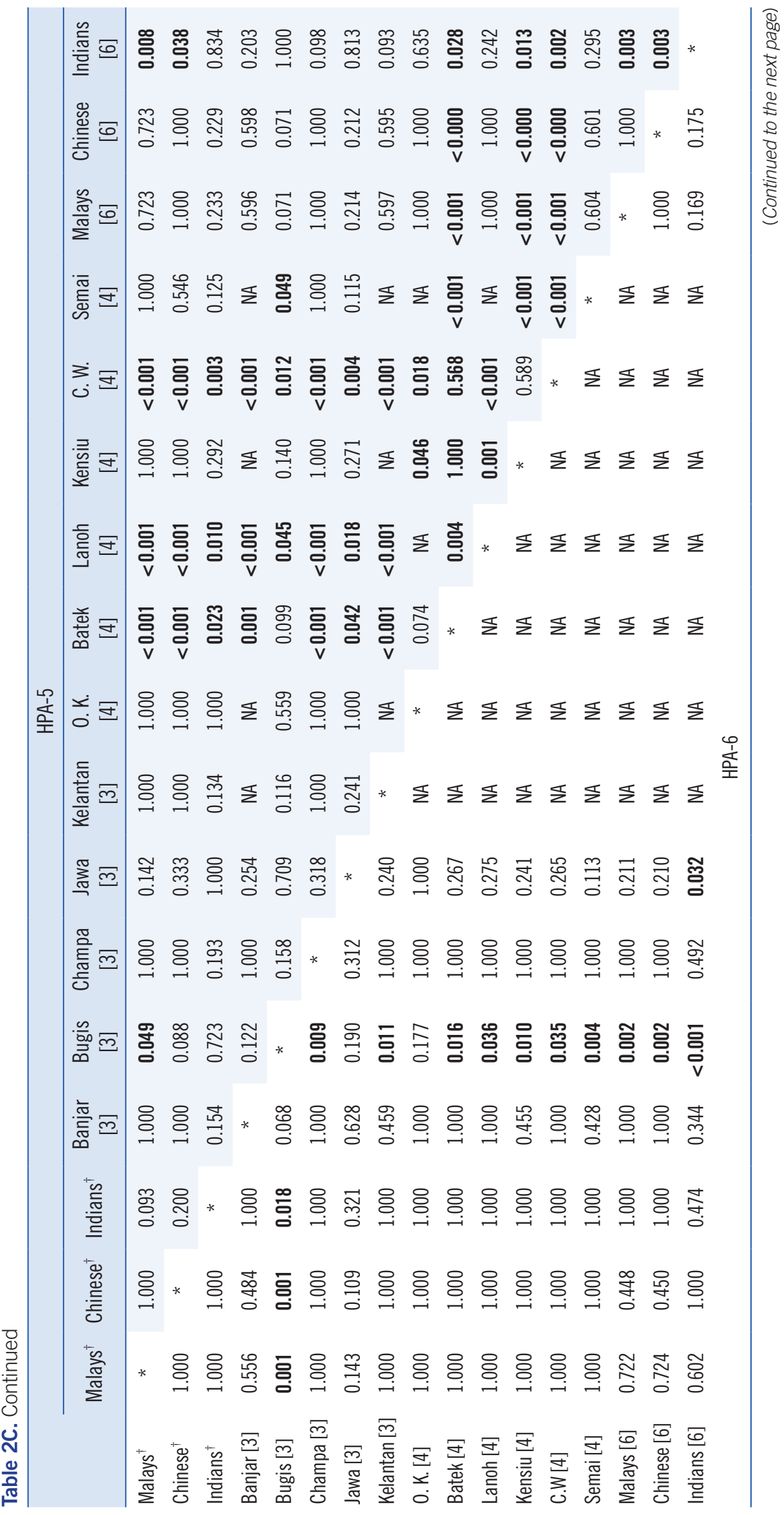




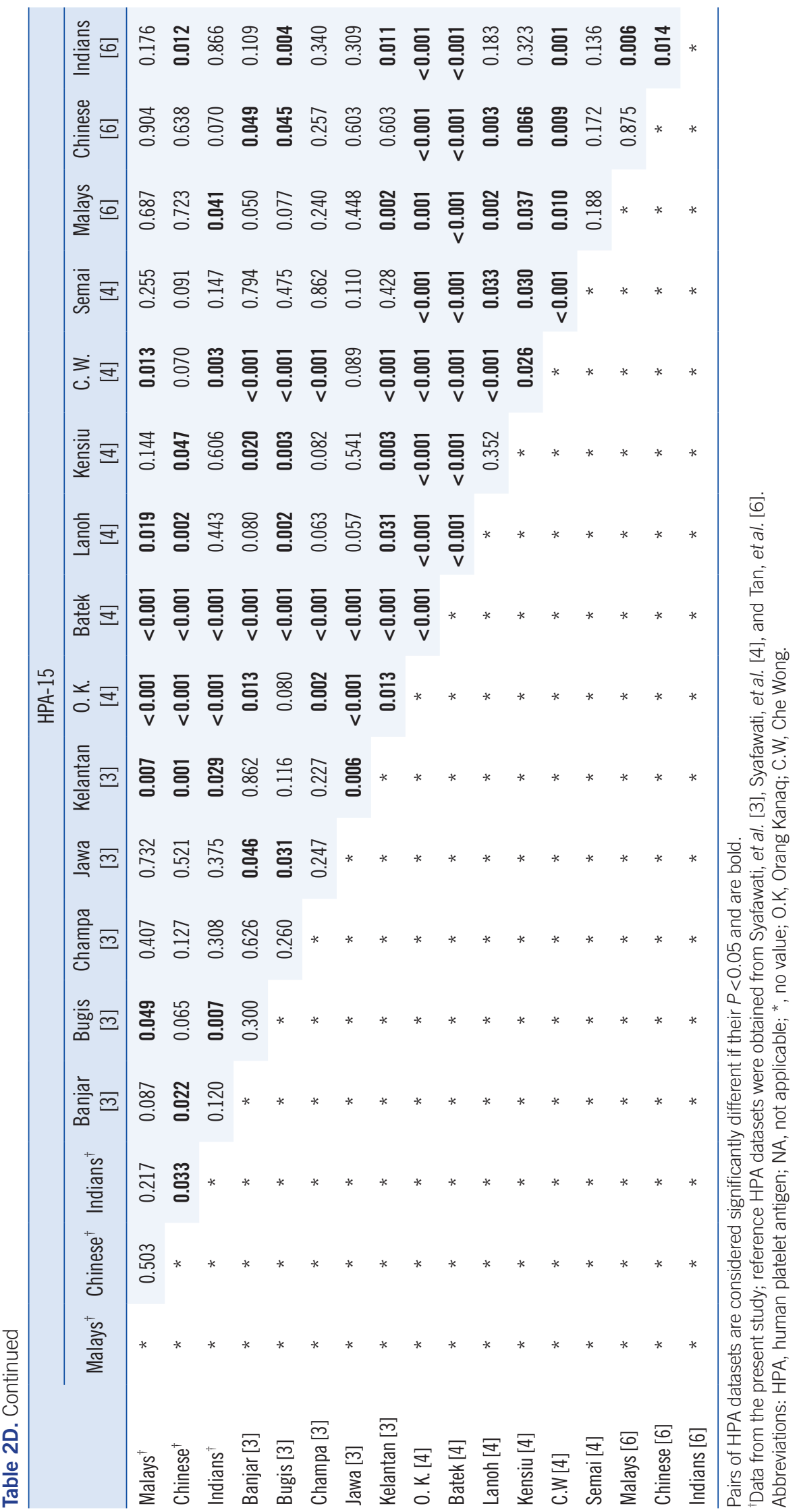




\section{ACKNOWLEDGEMENTS}

We are grateful to the volunteers and patients who contributed to this study. We specifically thank all the nurses and doctors who helped collect the blood samples.

\section{AUTHOR CONTRIBUTIONS}

CGNH designed and performed the research, collected the data, analyzed the data, and wrote the manuscript; ZZ helped design the study, managed sample collection, and obtained our ethics permit from the Ministry of Health, Malaysia; NSMR and THTM helped with study design, sampling, and data collection; $\mathrm{MNH}$, AMD, GEG, and GKC designed the study, advised on statistics, and edited the manuscript; and HAE designed and directed the study, advised on statistics, edited the manuscript, funded the research, managed the study, and obtained ethical approval from Human Ethics Committee, Universiti Sains Malaysia.

\section{CONFLICTS OF INTEREST}

No potential conflicts of interest relevant to this paper were reported.

\section{RESEARCH FUNDING}

This research was supported by a Short-Term Grant (304/PPSK 6315142) and Bridging Grant (304/PPSK/6316132) awarded by the Universiti Sains Malaysia to Hisham A. Edinur. Geoffrey K. Chambers wishes to thank the Victoria University of Wellington for Alumnus Scholar support.

\section{ORCID}

Che Ghazali Norul Hajar https://orcid.org/0000-0001-5152-1883 Zulkifli Zefarina

Nor Suhaila Md. Riffin https://orcid.org/0000-00032029-2234

Tuan Hulwani Tuan Mohammad

https://orcid.org/0000-0003-1606-2831

Mohd Nazri Hassan https://orcid.org/0000-0003-4975-2038

Ameer Mohamed Dafalla https://orcid.org/0000-0003-2928-4396 Gehad ElGhazali https://orcid.org/0000-0001-9514-3765 Geoffrey Keith Chambers Hisham Atan Edinur https://orcid.org/0000-0003-1019-6855 https://orcid.org/0000-0002-3379-6063

\section{REFERENCES}

1. Robinson J, Mistry K, McWilliam H, Lopez R, Marsh SG. IPD- the immuno polymorphism database. Nucleic Acids Res 2010;38:D863-9.

2. Saleh RM, Zefarina Z, Che Mat NF, Chambers GK, Edinur HA. Transfusion medicine and molecular genetic methods. Int J Prev Med 2018; 9:45

3. Wan Syafawati WU, Norhalifah HK, Zefarina Z, Zafarina Z, Panneerchelvam S, Norazmi MN, et al. Allele frequencies of human platelet antigens in Banjar, Bugis, Champa, Jawa, and Kelantan Malays in Peninsular Malaysia. Transfus Med 2015;25:326-32.

4. Syafawati WU, Zefarina Z, Zafarina Z, Hassan MN, Norazmi MN, Panneerchelvam S, et al. Human platelet antigen allelic diversity in Peninsular Malaysia. Immunohematology 2016;32:143-60.

5. Hajar CGN, Zulkafli Z, Md Riffin NS, Tuan Mohammad TH, Safuan S, Nelson BR, et al. Human neutrophil antigen frequency data for Malays, Chinese and Indians. Transfus Apher Sci 2019:102651.

6. Tan JY, Lian LH, Nadarajan VS. Genetic polymorphisms of human platelet antigens- 1 to -6 , and -15 in the Malaysian population. Blood Transfus 2012;10:368-76.

7. Excoffier L, Laval G, Schneider S. Arlequin version 3.0: an integrated software package for population genetics data analysis. Evol Bioinform Online 2007;1:47-50.

8. Norhalifah HK, Syaza FH, Chambers GK, Edinur HA. The genetic history of Peninsular Malaysia. Gene 2016;586:129-35.

9. Edinur HA, Dunn PP, Lea RA, Chambers GK. Human platelet antigens frequencies in Maori and Polynesian populations. Transfus Med 2013; 23:330-7.

10. Wan Mahmood WH and Mustaffa R. Platelet alloantibody in multiply transfused thrombocytopenic patients. Int Med J Malaysia 2007;6:1-10. 